\title{
Complement analysis reveals new biomarkers in patients with juvenile idiopathic arthritis
}

\author{
Juergen Brunner*, Thomas Giner, Reinhard Wuerzner \\ From 21st European Pediatric Rheumatology (PReS) Congress \\ Belgrade, Serbia. 17-21 September 2014
}

\section{Introduction}

The juvenile idiopathic arthritis is a well researched disease in the group of autoimmunopathies. Beside the deregulation of T-cells and cytokines also the complement system is involved in the pathogenesis of this group of diseases.

\section{Objectives}

This prospective longitudinal study investigated the contribution of the complement system in patients with juvenile idiopathic arthritis, using practicable ELISA techniques (Wieslab ${ }^{\circledR}$ screening kit; SC5b9 soluble terminal complement complex ELISA).

\section{Methods}

Serum and plasma of the peripheral blood and the synovial fluid were investigated for the activity of the three complement pathways - classical (CP), mannose binding lectin (MBL), and the alternative pathway (AP) and total complement activity by measuring SC5b9. Results where compared to published reference controls and 18 children without activation of inflammation as an age matched control group.

In total 57 samples of peripheral blood (PB) and 8 samples from synovial fluid (SF) from 28 children with JIA were investigated in a longitudinal observation during acute phase and remission.

\section{Results}

The screening of complement system showed debasement of the AP (8 of 10) and CP (7 of 10) in patients during acute phase (7 of 10). The SC5b9 measurement showed a significant $(\mathrm{p}<0.002)$ higher amount in plasma $(3,6 \mathrm{AU} / \mathrm{ml}$ in median) and serum $(31,4 \mathrm{AU} / \mathrm{ml})$ during

Medical University Innsbruck, Innsbruck, Austria acute phase compared to the control group (serum $7,72 \mathrm{AU} / \mathrm{ml}$ and plasma $-1,25 \mathrm{AU} / \mathrm{ml}$ in median).

\section{Conclusion}

In conclusion the study confirmed, that the $\mathrm{CP}$ and $\mathrm{AP}$ of the complement system are main contributors in the pathogenesis of JIA. Because of significant elevation of SC5b9 in acute phase of JIA, complement blockade with Anti-C5 may be a therapeutically option in the future.

\section{Disclosure of interest}

None declared.

Published: 17 September 2014

doi:10.1186/1546-0096-12-S1-P32

Cite this article as: Brunner et al:: Complement analysis reveals new biomarkers in patients with juvenile idiopathic arthritis. Pediatric Rheumatology 2014 12(Suppl 1):P32.
Submit your next manuscript to BioMed Central and take full advantage of:

- Convenient online submission

- Thorough peer review

- No space constraints or color figure charges

- Immediate publication on acceptance

- Inclusion in PubMed, CAS, Scopus and Google Scholar

- Research which is freely available for redistribution
() Biomed Central 